\title{
The rise and fall of ancient Egypt? Egyptology's never-ending story
}

\section{William Carruthers*}

In an op-ed piece on The Wall Street Journals website promoting his latest book, The Rise and Fall of Ancient Egypt (Wilkinson, T. 2010), Toby Wilkinson draws parallels between events in Egypt's past to those in its present. "The current situation in Egypt", we are told, "comes as no surprise to a student of the country's long history" (Wilkinson, T. 2011). It is only appropriate to observe, then, that the problematic nature of Wilkinson's book comes as no surprise to a historian of Egyptology. Both it — and the accompanying comparison of the country's past to its present - are part of a long tradition (although tradition is too positive a word) of questionable Egyptological analysis.

This tradition presents a narrative, centred on the origins and eventual dominance of Western civilisation, that dooms Egypt to an eternity of being viewed as inferior to Western modernity. Ancient Egypt is interpreted as a progenitor of Western civilisation, but the country declined and slipped into stagnation whilst the grand march of civilisation made its way onwards through Greece. Others have, of course, noted this narrative before, particularly with respect to its links to colonialism (e.g. Colla 2007: 14), hardly a positive lineage. However, some examples from the twentieth century would be useful to illustrate its longevity. Thus, the preface to the first edition of the first volume of the Cambridge Ancient History (subtitled Egypt and Babylonia to 1580 BC), published in 1923, stated that the series was "a continuous history of European peoples ... [but] the history of Europe begins outside Europe" (Bury et al. 1923: v). Egypt was important, but only momentarily. The same preface states that "in the next volume a new age opens up ... Greeks whose names were well remembered in Greek records will come upon the stage" (Bury et al. 1923: vii).

Meanwhile, John Wilson's 1951 volume, The Burden of Egypt: An Interpretation of Ancient Egyptian Culture, essentialised ancient Egypt as a discrete culture-historical entity which was once successful, but that experienced a "long petrifaction after $1100 \mathrm{BC}$ " (Wilson 1951:308). Whilst more cautionary about cultural inheritances than the Cambridge Ancient History, Wilson was still prepared to note that "the Greeks acknowledged ... that they had learned a great deal from Egypt ... and that this had been formative in their own lives" (Wilson 1951: 316-17). Egypt had stagnated, but its influence lived on - although, by implicit contrast, it was an inferior one; the country's age of glory was, after all, no longer.

Egyptology is supposed to be about the past but, instead, often illustrates negative attitudes (bordering on the racist) towards Egypt's present; the Egyptians, since they declined, are implicitly interpreted as inferior (and perhaps, then, ripe for colonisation). Wilkinson's op-ed and book - particularly taken in conjunction with one another — are a perfect illustration

Department of History and Philosophy of Science, University of Cambridge, Free School Lane, Cambridge CB2 3RH,UK (Email:wec24@cam.ac.uk) 


\section{William Carruthers}

of this tradition, even if unintentional. For example, in the op-ed, Wilkinson states that, from the pharaonic period onward, there has never been a custom of political debate in Egypt. What he means by 'political debate' is unclear but, if one takes into consideration political activism, then it is clear that such a tradition does exist.

To give some examples, there have been revolutions in 1879-1882, 1919, 1952 and, of course, 2011. Egypt is as politicised as any other country. Did Wilkinson inherit his thinking from Egyptology's constant assertion of the unchanging nature of the Egyptian peasant (cf. Mitchell 2002), doomed - particularly, one suspects, after Egypt's supposed final decline - to passivity? When read in conjunction with the title of Wilkinson's book, the sub-text is clear. Egypt was once, perhaps, great, but not anymore (it is not, after all, the West).

Meanwhile, Wilkinson describes the events in Egypt in early 2011 as "deeply troubling to Western observers" (Wilkinson, T. 2011), suggesting perhaps that an Egyptian form of political debate is uncomfortably outside the narrative prescribed to the country. Furthermore, his statement that the country's passing glory was tempered with brutality — with rulers who were "despotic" (2010: 10) — is uncomfortably close to the age-old (and hugely problematic) trope of 'oriental despotism'. Even if unintentional — Wilkinson's aim in making this statement is to help provide a "more balanced picture of ancient Egyptian civilisation" (2010:10) — one cannot help feeling that the phrase simply plays to the crowd who think that the Middle East faces an eternity of despotic rulers. Wilkinson's (2011) comparison of ex-President Mubarak to a pharaoh - even if a popular trope in Egypt itself - does nothing to dispel this thought. Given that the West was complicit in keeping Mubarak and his ilk in power, it is a somewhat sobering comparison.

Meanwhile, an indication of the continuing inertia of approaches to Egyptology may be seen by comparing Wilkinson's chapter titles with those of Wilson 60 years before. Thus, whilst Wilson (1951) began with 'Out of the mud: the long prehistoric struggle', Wilkinson (2010) also starts off with something of a creation story: 'In the beginning'. Indeed, whilst Wilson was understated in his biblical allusions - The Burden of Egypt is a quote from the book of Isaiah — Wilkinson is gratingly unsubtle: does he really need to talk about 'Heaven on Earth' and 'Paradise postponed'? It merely adds to the impression that Egypt really is a progenitor of (Christian) Western civilisation, a viewpoint he seems keen to impart (2010: 512). Given how troubling this view is when considering Egypt's role in other religious arenas (Islam, for example), not to mention the West's often problematic treatment of them, such chapter titles are, to say the least, unsettling.

Additionally, whilst Wilson used 'The first illness' to discuss Egypt's First Intermediate period, Wilkinson uses 'The end of innocence' as the section title which encompasses that period's discussion. Later, Wilson talks of 'Far frontiers' whilst Wilkinson talks about 'Pushing the boundaries'. Towards the end of events, Wilson has 'The broken reed' (an allusion to a description of a decaying Egypt, again from Isaiah), whilst Wilkinson has 'A tarnished throne'. Wilkinson's chapter headings are similar, then, to those from 1951, a year in which, in a feat of publicity worthy of Mad Men, Wilson's colleague, the Sumerologist Thorkild Jacobsen, suggested to The University of Chicago Press that The Burden of Egypt would "be of special interest to Jewish groups and to negroes" (Chicago archives).

It is time to move on. It is no longer responsible to rehash the age-old narrative of ancient Egypt, even if in a 'balanced' way; it merely serves to aggrandise those who still believe in the 
inevitability of Western superiority, and reinvigorate stereotypes of a stagnant and despotic Egypt (not to mention the wider Middle East and Islam). To emphasise the validity of this critique, it can be equally applied to the continued profusion of textbook-like tomes that are being published relating to ancient Egypt. For example, the contents of The Oxford History of Ancient Egypt (Shaw 2000) provide various detailed renderings of discrete periods within what is perceived to be ancient Egyptian time. However, that it is ancient Egyptian time is still defined by where those contents end; they do not progress beyond Greek and Roman dominance of the country.

Meanwhile, the collection Egyptology Today (Wilkinson, R. 2008) claims to examine 'how modern scholars study all aspects of ancient Egypt, one of the greatest of all ancient civilisations'. Once again, ancient Egypt is put in its place. It occupies a discrete place in space and time, which only the more advanced progenitors of Western modernity are in a position to understand. Pertinently, the volume includes not a single contribution from an Egyptian author (rather similar to The Oxford History). Meanwhile, Western countries such as America consistently attempt to reimpose their supposed superiority and expertise through convoluted 'aid' deals; as they have sold their technology to Egypt (Mitchell 2002: 238), so too have they sold Egyptological expertise.

Reading these volumes, then, one is always left with a slightly bitter aftertaste. Despite the undoubted expertise of some of the contributors, the sub-text is that the West knows best. Ancient Egypt is still being presented as a discrete culture-historical moment, an essentialised category with essentialised meanings. The point is to buy the book, find out what those meanings are, and perpetuate them - regardless of other interpretations that might exist (see e.g. Montserrat 2000; Colla 2007 for analysis of other approaches). That such textbooks also connect themselves to modernity seems inevitable — as noted above, it is (Western) modernity that really perceives itself as knowing ancient Egypt.

Additionally, by its very mention, ancient Egypt (and everything problematic that has been associated with its study) lives on. Of course, it is probably too much to hope that people might entirely stop thinking about it in the ways that Egyptologists (or believers in extra-terrestrial pyramid builders, for that matter) have formulated. However, recent events in Egypt have proven that change is possible (not to mention desired). Can't Egyptologists begin that process, too? A little historical awareness would go a long way.

\section{Acknowledgements}

I would like to thank the staff of the University of Chicago Archives for their help in giving me access to the archival material quoted in this paper. I would also like to thank Martin Carver for his encouragement and editorial suggestions.

\section{References}

Bury, J.B., S.A. CoOK \& F.E. AdCOCK. 1923. Preface, in J.B. Bury, S.A. Cook \& F.E. Adcock (ed.) The Cambridge ancient history. Volume I: Egypt and Babylonia to 1580 BC: v-x. Cambridge: Cambridge University Press.
Chicago Archives. Archives of the University of Chicago Press: Records 1892-1965, Box 495, Folder 3; Hemens to 'EW', 15 March 1951.

Colla, E. 2007. Conflicted antiquities: Egyptology, Egyptomania, Egyptian modernity. Durham (NC) \& London: Duke University Press. 


\section{William Carruthers}

MitCHeLl, T. 2002. Rule of experts: Egypt, techno-politics, modernity. Berkeley (CA): University of California Press.

MontSerrat, D. 2000. Akhenaten: history, fantasy and ancient Egypt. London \& New York: Routledge.

SHaW, I. (ed.) 2000. The Oxford history of ancient Egypt. Oxford: Oxford University Press.

WiLKINSON, R.H. (ed.) 2008. Egyptology today. Cambridge: Cambridge University Press.

WILKINSON, T.A.H. 2010. The rise and fall of ancient Egypt: the history of a civilisation from 3000 BC to Cleopatra. London: Bloomsbury.
-2011. The tradition of the pharaohs lives on: lessons from Ozymandias, Horembeb, and the untimely death of the boy-king Tutankhamun. Available at: http:// online.wsj.com/article/SB1000142405274870470$9304576124461259744494 . h t m l ? \bmod =W_{S} J_{-}$ LifeStyle_LS_Books\&dm_i=D9F\%2CCZ8V\% 2C2P0DKY\%2C10XOC\%2C1\# articleTabs\% 3Darticle (accessed 11 April 2011).

WILSON, J.A. 1951. The burden of Egypt: an interpretation of ancient Egyptian culture. Chicago (IL): University of Chicago Press. 